\title{
WHAT WAS A "FLOATING DISTRICT?"
}

We were lately asked to explain what is meant by the term "floating district," as used in Alrticle 3 , Section 35, of our present State Constitution. Previous to 1858 the legislature constituted representative and senatorial districts which came to be known by this popular designation. The easiest way to explain the matter is probably by reference to the act providing for the representative apportionment of 1857.* Section 49 enacts that "The county of Van Buren shall constitute the forty-ninth representative district, and have two representatives." Section. 53 makes Henry county the 53rd district, with two representatives. Section 43 makes the county of Lee the 54th district, with three representatives. But section 55 of this act declares that "The counties of Lee, Henry and Van Buren, shall jointly constitute the 55th representative district and have one representative." This last was a "floating district," though it would seem that the term should have applied rather to the representative than to the district from which he was chosen. The act referred to provides for five of these "floating districts." The usage had existed many years in the apportionment laws applying to both branches of the General Assembly. This custom was liable to much abuse, and in time became quite unpopular. The purpose for which a "floating district" was constituted was no doubt to give each of the counties of which it was composed its fair share of representation for its excess of population over that required tc elect one or more members. The injustice arose from the fact that the "floating" member was pretty apt to represent his own county or locality and ignore the balance of his alleged and often attenuated constituency. Abuses crept in, as

* :Acts, Resolutions and Memorials, passed at the Regular Session of the Sixth General Assembly of the State of "Iowa, 1857," Chap. 132, pp. 170-174. 
gerrymandering, "log-rolling and corruption in the legislature," and the erection of such districts for purely individual, local or partisan purposes. The subject was freely debated in the constitutional convention of 1857 , * by Messirs. J. C. Hall, J. A. Parvin, A. H. Marvin, D. H. Solomon, Amos Harris and J. C. Traer. Section 35, Article 3, of the Constitution of our State closes as follows: "Provided, further, that no floating district shall hereafter be formed." This inhibition at once stopped the practice, and the term "floating district" has fallen into such "innocuous desuetude" that at this day people are inquiring what it meant.

* Iowa Constitutional Debates, 1857, vol, 1, pp. 543-548

THE cut of the old blockhouse and barracks at Council Bluffs, which illustrates $\mathrm{Mr}$. Bloomer's interesting article, was made from a pencil drawing by $\mathrm{Mr}$. Charles Simons of that city. He saw them not long after they were erected and was familiar with their appearance. Other old residents of Cuuncil Bluffs recognize this sketch as conveying a good idea of the appearance of these prim. itive structures.

\section{NOTABLE DEATHS.}

Generat George Wathace Jonks died at his homo in Dubugne, July 22,1896 . Born at Vincennes, Indiana, A pril 12, 1804, he was a drummer boy in the war of 1812, and won distinction in the Black Hawk war. He was the last delegate in congress from Michigan, the first delegatefrom Wisconsin and one of the first United States senators from the state of Iowa, and he selected the hames. Wisconsin and Jowa. He had known every president since Monroe, was in the escort of Liafiayette, was a business partner of Daniel Welster, was the colleagne in congress of̂ Thomas H. Benton, Charles Sumner, Stephen A. Douglas, William H. Seward and James Buchanan, was the intimate friend of John C. Calhoun, Martin Van Buren, Henry Clay, John C. Fremont, Jefferson Davis and Franklin Pieree, was an minister to South America before the war, was a party to seven "affairs of honor," caught the dying victim of the Cilley-Graves duel in his arms, was imprisoned by Seward on suspicion of being in collusion with Jefferson Davis, was the Chesterfield of Washington society nearly fifty years ago; was once the richest man in Iowa, but in his latter years has had little income except 
Copyright of Annals of Iowa is the property of State of Iowa, by \& through the State Historical Society of Iowa and its content may not be copied or emailed to multiple sites or posted to a listserv without the copyright holder's express written permission. However, users may print, download, or email articles for individual use. 